\title{
Active caspase-3 expression levels as bioindicator of individual radiosensitivity
}

\author{
NEYLIANE F.G. DOS SANTOS ${ }^{1}$, RAFAEL F. SILVA ${ }^{2}$, MARCELA M.P.L. PINTO ${ }^{1}$, \\ EDVANE B. DA SILVA ${ }^{1}$, DEBORAH R. TASAT ${ }^{3}$ and ADEMIR AMARAL ${ }^{1}$ \\ ${ }^{1}$ Laboratório de Modelagem e Biodosimetria Aplicada/LAMBDA, Departamento de Energia Nuclear, Universidade \\ Federal de Pernambuco, Av. Prof. Luiz Freire, 1000, Cidade Universitária, 50740-540 Recife, PE, Brazil \\ ${ }^{2}$ Departamento de Ciências Naturais e Exatas, Universidade de Pernambuco, Rua Capitão Pedro \\ Rodrigues, de 87/88 ao fim, Bairro Magano, 55294-310 Garanhuns, PE, Brazil \\ ${ }^{3}$ Laboratory of Lung Cell Biology, National University of General San Martín, 5445, Avda. \\ Gral Paz, INTI- Ed. 23, San Martín, Buenos Aires, UK 1650, Argentina
}

Manuscript received on October 10, 2016; accepted for publication on January 11, 2017

\begin{abstract}
Several molecules and events involved in cell response to radiation-induced damage have been investigated towards a personalized radiotherapy. Considering the importance of active caspase- 3 in the proteolytic cascade that ensures radiation-induced apoptosis execution, this research was designed to evaluate the expression levels of this protein as a bioindicator of individual radiosensitivity. Peripheral blood samples of 10 healthy individuals were gamma-irradiated (cobalt-60 source) with 1,2 and 4 Gy (control: non-irradiated samples), and active caspase-3 expression levels were measured in lymphocytes, by flow cytometry, ex vivo and after different times of in vitro incubation (24, 48 and 72 hours). Short-term incubation of $24 \mathrm{~h}$ was the most adequate condition to evidence correlations between dose radiation and active caspase- 3 expression. For each radiation dose, it was observed a significant inter-individual variation in active caspase-3 expression intensity, suggesting that this parameter may be suitable for evidence individual radiosensitivity. The methodology presented and discussed in this work may help to predict healthy tissues response to radiation exposure toward the better patient outcome.
\end{abstract}

Key words: active caspase-3, apoptosis, flow cytometry, ionizing radiation, lymphocytes.

\section{INTRODUCTION}

In searching for a biology-based personalized radiation therapy (RT), researchers have been focused on the better understanding of lethal and carcinogenic effects of ionizing radiation (IR), at the molecular, cellular and tissue levels.

Correspondence to: Neyliane Frassinetti Gonçalves dos Santos E-mail: neyliane@gmail.com

* Contribution to the centenary of the Brazilian Academy of Sciences.
The contribution of those works on radiological protection is widely known and, more recently, radiation oncologists have shown great interest in such issues, aiming to improve the effectiveness of radiotherapy by protecting healthy tissues (Joubert et al. 2011, Choi and Cho 2016).

The field of major interest and impact in radiobiology is the cellular response to radiation-induced damage in the molecule of deoxyribonucleic acid (DNA), especially in terms of biochemical 
cascades initiated by DNA double-strand breaks (DSB), since this is the main type of damage related to carcinogenic and lethal effects of radiation (Rodemann and Wouters 2011, Selzer and Hebar 2012).

DSB triggers a sophisticated molecular circuit that involves proteins that are hypo- or hyperregulated in order to execute the cellular response to DNA damage (Daub 2012, Agarwal and Miller 2016). These proteins can release biochemical signals acting on other proteins, commonly associated with progression or inhibition of cell cycle, or to repair system (Ross and Kaina 2013, Lavin et al. 2015). If the damage is not repaired, cells can accumulate mutations, chromosomal aberrations and changes in cell proliferation, or even, undergo cell death (Matt and Hofmann 2016).

Apoptosis is the principal cell death process in response to radiation stress, and it is triggered in order to eliminate seriously damaged cells, on inflammation-free processes (Eriksson and Stigbrand 2010, Maier et al. 2016). This programmed cell death involves a complex series of molecules, localized in various cellular compartments, that mediate the process through either p53-dependent or -independent mechanisms, related to mitochondria (intrinsic pathway) or even to membrane (extrinsic pathway). Regardless the initiation route, all events converge on a common signaling cascade involving a group of proteases called caspases (cysteinyl aspartate proteinases) (Maier et al. 2016, Matt and Hofmann 2016).

Caspases take part of a complex and highly coordinated event leading to biochemical changes, which in turn culminate in morphological and structural features that characterize apoptotic cells (Kuranaga 2010, Savistskaya and Onishchenko, 2015). In this proteolytic cascade, one active caspase activates a procaspase, amplifying the apoptotic signaling pathway to cell death in an apparently irreversible way. The final pathway of apoptosis consists of the execution phase, where caspase-3, -6 and -7 are the main actors (McIlwain et al. 2013, Bolkent et al. 2016).

Caspase-3 has been considered the primary executioner of the apoptotic process. Activated by any initiator caspase $(-8,-9$ or -10$)$, caspase- 3 acts directly cleaving or catalyzing the cleavage of hundreds of cellular protein substrates, mainly related to chromatin condensation and margination, DNA fragmentation and nuclear collapse (Elmore 2007, Palai and Mishra 2015). Indeed, caspase-3 inhibition has been associated with necrotic characteristics, indicating the crucial importance of the activity of this protein on the occurrence of apoptosis after exposure to IR (Coelho et al. 2000, Garcia-Belinchón et al. 2015). Depletion of the others executioner caspases (caspase- 6 or -7 ) has shown minimal impact on the apoptotic process (Slee et al. 2001), and even caspase-7 cleavage seems to be mostly processed by active caspase-3 (Trisciuoglio and Bianchi 2009, Matt and Hofmann 2016).

On radiation cellular response investigation, blood is considered an easy resource to study genotoxicity and to estimate the effects of radiation. Lymphocytes have been the most widely employed model, due to its high radiosensitivity, accessibility and high concentrations in peripheral blood (Cozzarini 2015, Sridharan et al. 2016, Tewari et al. 2016). This kind of cell is particularly interesting for analysis of radiation-induced apoptosis due to its readiness to undergo apoptosis following irradiation (Jella et al. 2013, Ogawa 2016). Thus, the purpose of this research was to investigate radiation-induced apoptosis in quiescent (G0) human lymphocytes by flow cytometric measurement of active form caspase-3 expression, aiming to evaluate the expression levels of this protein as a bioindicator of individual radiosensitivity. To define the adequate incubation condition to perform such analyses, the active caspase- 3 expression was analyzed in nonmitogen-stimulated lymphocytes, ex vivo and at different in vitro incubation time points. 


\section{MATERIALS AND METHODS}

\section{STUDY POPULATION AND ETHICAL ASPECTS}

The present study was conducted with 10 healthy volunteers, 6 women and 4 men aged 19 to 44 years (mean 28.8 years). None of them underwent medical procedures involving IR or mutagenic chemicals, at least three months before this study. This research complies with the Declaration of Helsinki and was performed following recommendations of the Committee of Ethics in Research involving Humans at the Health Sciences Center of the Federal University of Pernambuco (n. 297/09). Informed consent form was obtained from all participants before sample collection and use of questionnaire data.

\section{BLOOD SAMPLES AND IRRADIATION SETUP}

From each volunteer, a sample of venous peripheral blood was collected in heparinized tubes. The total sample was divided into four aliquots: one was kept as non-irradiated control, while the three others were separately gamma-irradiated in a cobalt-60 source (GammaCell-220, Radionics Laboratory, USA - dose rate: $3.7 \mathrm{~Gy} / \mathrm{h}$ ), receiving respectively 1, 2 and 4 grays (Gy).

\section{ISOLATION AND INCUBATION OF LYMPHOCYTES}

Following the standard method recommended by the manufacturer of Ficoll Paque density gradient media (GE Healthcare, USA), each fresh blood aliquot was diluted in an equal volume of phosphatebuffered saline (PBS, pH 7.2-7.4), carefully layered over Ficoll gradient (diluted blood:ficoll, 3:1) and centrifuged at $400 \times \mathrm{g}$, for $35 \mathrm{~min}$. Mononuclear cells layer was recovered and washed with PBS, and then centrifuged $(250 \mathrm{x} \mathrm{g}, 10 \mathrm{~min})$. The final pellet was resuspended in Roswell Park Memorial Institute 1640 medium (RPMI-1640 medium) (Cultilab, Brazil) supplemented with $10 \%$ heatinactivated fetal bovine serum (Cultilab, Brazil) and cell viability was assessed by trypan blue exclusion test (Sigma-Aldrich, USA).

For ex vivo analyses, an aliquot of the cell suspension was directly processed for flow cytometry while for in vitro analysis, cells were seeded into flat-bottom 96-well plates with supplemented RPMI media (like described above) and incubated at $37{ }^{\circ} \mathrm{C}$ in a humidified $5 \% \mathrm{CO}_{2}$ atmosphere, for 24, 48 and 72 hours (h). This procedure has been presented previously elsewhere (Santos et al. 2013).

\section{FLOW CYTOMETRY}

\section{Intracellular staining}

Active caspase-3 staining protocol was performed following manufacturer's instructions (PE active caspase-3 apoptosis kit, BD Pharmingen). Harvested cells were transferred into $5 \mathrm{~mL}$ polystyrene tubes $\left(6 \times 10^{5}\right.$ cells/tube $)$ and the cell culture medium was removed by centrifugation (300 x g, $5 \mathrm{~min}$ ). Cells were washed once with icecold PBS (300 x g, $5 \mathrm{~min}$, for solution removal), and then fixed and permeabilized with buffer containing paraformaldehyde $4 \%$ and saponin 0.1 $\%$ (BD Cytofix/Cytoperm, USA) during $20 \mathrm{~min}$, on ice. After buffer removal ( 400 x g, 5 min), cells were washed twice with a solution containing saponin, fetal bovine serum and sodium azide (BD Perm/ Wash 1X, USA - referred here as permeabilizing/ washing solution), centrifugating at $400 \mathrm{x}$ g, $5 \mathrm{~min}$. Then, cells were resuspended in this same solution for labeling with monoclonal antibodies.

Non-irradiated and irradiated cells were labeled with anti-active caspase-3-phycoerythrin (PE) (BD Pharmingen, USA, clone C92-605). For initial setup of cytometer and detection of unspecific fluorescence, additional aliquots of nonirradiated cells were maintained without labeling and labeled with anti-immunoglobulin G (IgG)-PE (BD Phosflow, USA), respectively. Incubation was performed in the dark, for $30 \mathrm{~min}$, and antibody 
excess was removed by washing of cells with permeabilizing/washing solution, followed by centrifugation ( $400 \mathrm{x} \mathrm{g}, 5 \mathrm{~min}$ ). Finally, cells were resuspended in this same solution, maintained at 4 ${ }^{\circ} \mathrm{C}$ until reading.

\section{Acquisition and analysis of data}

Data acquisition was performed on Gallios flow cytometer (Beckman Coulter) equipped with a blue laser $(488 \mathrm{~nm})$, using software specific for this device (Gallios Software, Beckman Coulter). Equipment acquisition setup: forward scatter (FSC) and side scatter (SSC), with linear amplification and FSC threshold set; and yellow-orange fluorescence (FL2), with logarithmic amplification. At least, 50,000 events were acquired from each sample.

Data files were analyzed with Kaluza software (Beckman Coulter), using two-dimensional density plots and histogram. Lymphocytes were identified based on FSC and SSC parameters, and total protein expression was measured in percentage values, from this cell population.

\section{STATISTICAL ANALYSIS}

Analyses of active caspase- 3 expression data were performed using BioEstat version 5.3 software (Miramauá Institute). All data were expressed as mean \pm standard deviation (SD). Differences between means were evaluated by one-way analysis of variance (ANOVA) with post-hoc Student's T-test. Statistically significant differences were accepted for calculated probability $p<0.05$.

\section{RESULTS}

The protein-based assays have been developed to characterize radiation-induced cellular response, and to analyze the potential of such proteins as biomarkers of exposure, effect or susceptibility to IR (Bennett and Waters 2000, Kim et al. 2013). In the present work, the expression of active caspase-3 was evaluated for characterization of radiation-induced apoptotic cell death and then to analyze possibilities of employment on practices benefited by advances on radiobiology, particularly to a personalized RT.

Blood aliquots were separately exposed to 1 , 2 and $4 \mathrm{~Gy}$, which are dose levels with therapeutic relevance. Although conventional radiotherapy protocols employ 2 Gy daily fractions, new schedules aiming to preserve normal tissues or overcome tumoral repopulation may involve hyperor hypo-fractionation, in order to deliver smaller or higher doses per fraction, respectively (Marcu 2010, Deloch et al. 2016).

Regarding post-radiation exposure, the expression level of active caspase- 3 was analyzed throughout the time range of $0-72 \mathrm{~h}$, over $24 \mathrm{~h}$ intervals.

MULTIPARAMETRIC ANALYSES FOR LYMPHOCYTE IDENTIFICATION AND CASPASE-3 EXPRESSION

Figure 1 shows two representative graphics obtained from flow cytometric analyses of $24 \mathrm{~h}$ incubated samples from one individual. The 2D-density plot (Figure 1-a) presents the mononuclear cells, with the lymphocyte population delimited on gate differentiation between lymphocyte and monocyte populations was based on correlation of FSC and SSC parameters (that indicate cell size and internal complexity, respectively). The histogram (Figure 1-b) gathers data about active caspase- 3 expression levels from control (green line), 1 Gy (orange line), 2 Gy (blue line) and 4 Gy-irradiated samples (red line).

TIME COURSE ANALYSIS OF RADIATION-INDUCED CASPASE-3 EXPRESSION

Figure 2 presents the results of active caspase-3 mean expression levels for control (non-irradiated) and irradiated cells under ex vivo and in vitro conditions.

In the ex vivo analyses (immediately after irradiation), regarding active caspase- 3 expression, 

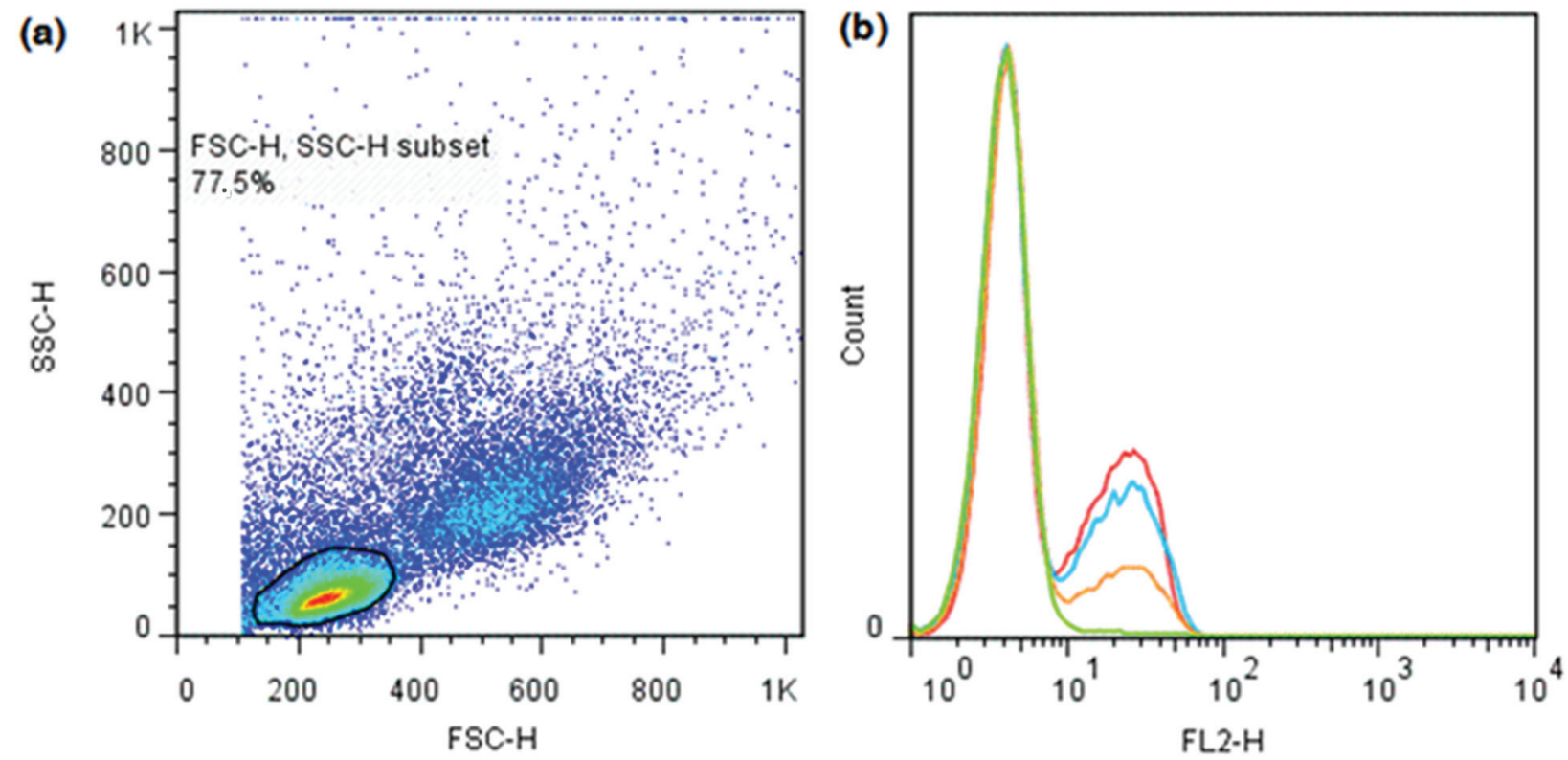

Figure 1 - (a) FSC/SSC 2D-density plot, with gate drawn around the lymphocyte population (b) FL2 histogram corresponding to active caspase-3 expression from gated lymphocytes, gathering data of non-irradiated (green), 1 Gy- (orange), 2 Gy- (blue) and 4 Gy-irradiated samples (red). The first peak (lower $10^{1}$ ) represents cells negative for active caspase- 3 expression, and the second peak (higher $10^{1}$ ), those positive to this parameter. The second peak height indicates positivity intensity, in a way that non-irradiated lymphocytes (green) were primarily negative for the presence of active caspase-3, whereas irradiated lymphocytes were positive for active caspase-3 staining, increasing for higher doses.

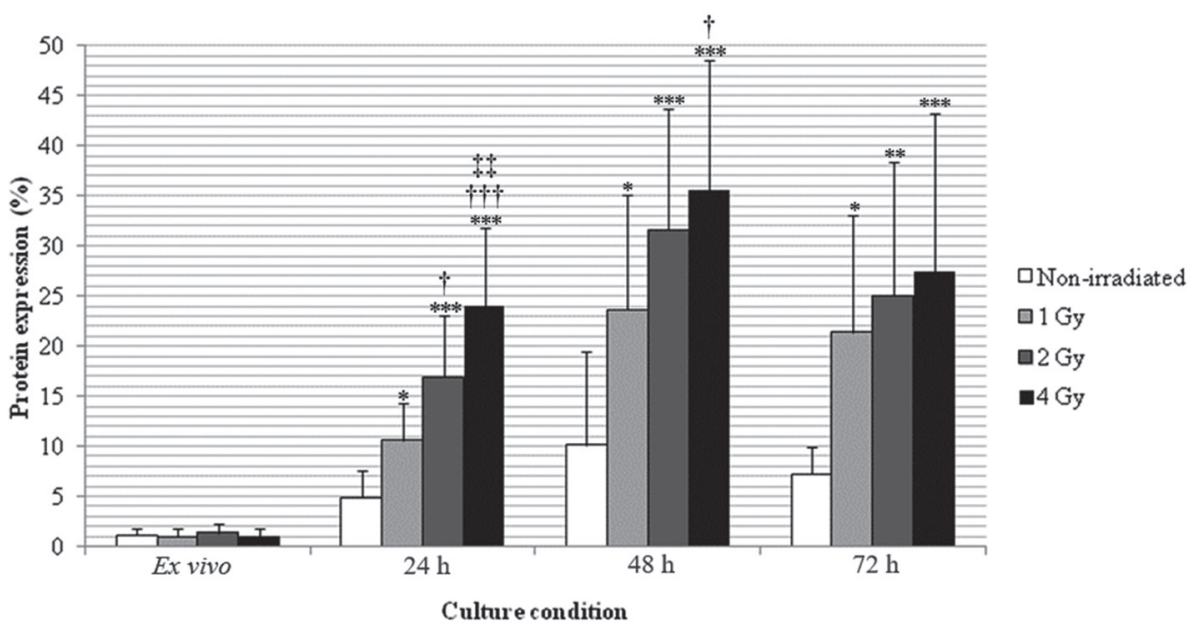

Figure 2 - Expression level of active caspase-3 on lymphocytes through time, for ex vivo or in vitro protocols. Bars show mean \pm SD. Symbols: *, for comparison with control group, $\dagger$ for comparison with 1 Gy-irradiated, and $\$$ for comparison with 2 Gy-irradiated. One symbol: $\mathrm{p} \leq$ 0.05 ; two symbols: $\mathrm{p} \leq 0.01$; three symbols: $\mathrm{p} \leq 0.001$.

irradiated cells could not be distinguished from nonirradiated ones. However, when these cells were incubated in vitro, it was observed a significant increase in the expression level of this protein in non-irradiated cells $(p<0.01)$, for all analyzed time points. The active caspase- 3 expression became higher after radiation exposure $(p<0.0001)$.

For the $24 \mathrm{~h}$ time point, it was possible to distinguish non-irradiated cells from irradiated ones, for all evaluated dose levels. Additionally, the 
active caspase-3 expression allowed differentiating among the three evaluated dose levels.

Considering the lymphocytes incubated for $48 \mathrm{~h}$, the results presented significant differences in active caspase-3 expressions for non-irradiated cells when compared with those irradiated. However, considering the irradiated cells, significant differences were only observed between the samples irradiated with 1 Gy and 4 Gy.

After $72 \mathrm{~h}$ incubation, significant differences of active caspase- 3 expression were found only in terms of non-irradiated and irradiated cells.

\section{INDIVIDUAL VARIATION}

Considering all in vitro analyses, a high standard deviation was observed, indicating that, beyond to dose-response relations, there is a wide difference among individuals on the magnitude of active caspase-3 expression levels $(p<0.001)$. To illustrate this interindividual evidence, Figure 3 presents data dispersion for the $24 \mathrm{~h}$ time point, which was the time point where the results allow a better fit between active caspase- 3 expression and radiation doses.

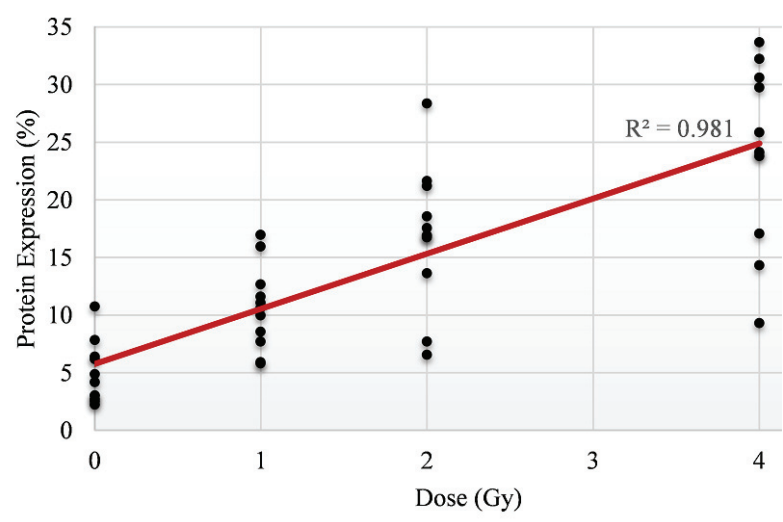

Figure 3 - Dispersion of active caspase-3 expression for lymphocytes incubated for $24 \mathrm{~h}$. Black dots symbolize individual data for each radiation dose $(\mathrm{n}=10)$, and red dots, mean values. The red line represents the linear trendline, displayed with coefficient of determination $\left(\mathrm{R}^{2}\right)$.
The trendline evidences positive linear relationship between the expression of active caspase- 3 and radiation doses. However, a significant spread out of individual data occurred around mean values $(p<0.001)$, particularly at the higher radiation doses ( 2 and $4 \mathrm{~Gy}$ ).

A better visualization of the radiation-induced response by each individual for $24 \mathrm{~h}$-analysis is shown in Figure 4.

\section{DISCUSSION}

Active caspase-3 expression levels were measured from lymphocytes incubated during 24 up to $72 \mathrm{~h}$ without phytohemagglutinin (PHA) stimulation, to avoid negative influence of this mitogenic stimulus on expression of the protein at issue. Ulsh (2010) defends that suppression of apoptosis is an effect of PHA, and this evidence is supported by the research of Kornacker et al. 2001, where following 48-96 hours of cell culture with mitogens like PHA occurs upregulation of survivin, a member of the inhibitors of apoptosis protein family that binds (and inhibits) the terminal effectors of caspase-3 and -7 .

The significant increase of basal expression of active caspase- 3 on cultures without PHA indicates that the in vitro incubation itself contributes to enhance active caspase- 3 expression levels in lymphocytes. This evidence may support two possibilities: (i) the lymphocytes were not able to adapt to in vitro incubation conditions and triggered cell death by apoptosis - process in which the role of active caspase-3 is indispensable (Palai and Mishra 2015); (ii) active caspase-3 participates on cell death-unrelated processes.

About this second possibility, Galluzzi et al. 2008 defend that any protein specifically implicated in apoptosis might have a phylogenetically conserved apoptosis-unrelated function, probably as part of an adaptive response to cellular stress. About this issue, Shalini et al. 2015 address multiple functions of caspases outside apoptosis. 


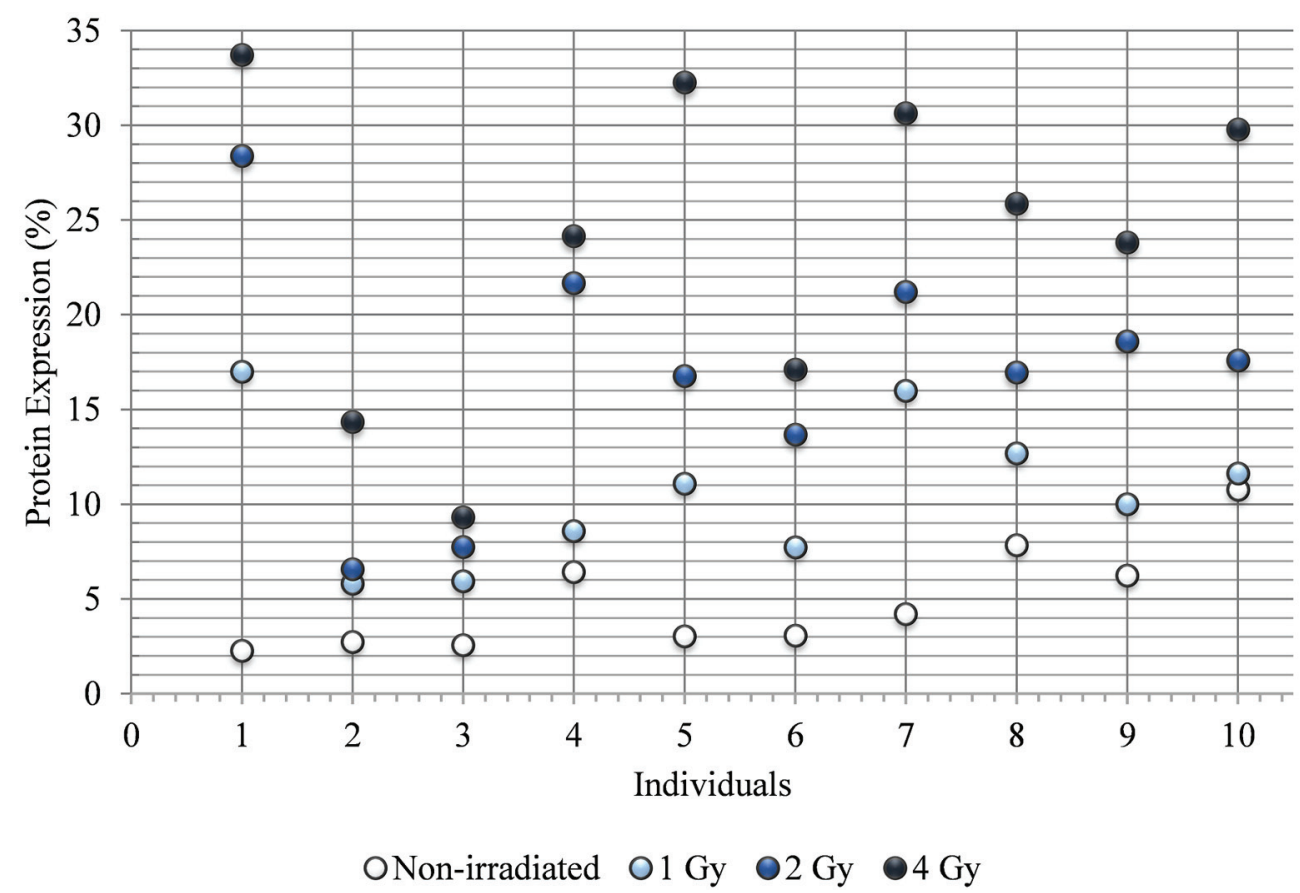

Figure 4 - Individual active caspase-3 expression on lymphocytes incubated for $24 \mathrm{~h}$, for non-irradiated and 1 Gy-, 2 Gy- and 4 Gy-irradiated cells.

As cell culture itself imposes a state of oxidative stress on cells (Halliwell 2003, 2014), this relevant increasing on basal expression levels of active caspase-3 may be a response to this condition, but its activation does not lead to death. It remains unclear how this caspase-3 activation does not lead to cell death - however, it has been proposed that, in parallel to caspase activation, cells may express antiapoptotic molecules (e.g. inhibitors of apoptosis protein family) or execute mechanisms like Ras GTPase activating protein (RasGAP) cleavage (Yang et al. 2004) and be able to tolerate low caspase activity in response to mild stresses (Launay et al. 2005, Khalil et al. 2012).

Radiation doses were chosen based on the context of radiation oncology as well as for radioprotection. The dose levels employed in this work can be associated to accidental overexposures (Pinto et al. 2010) as well as doses administered per session in conventional radiotherapy schedules (2-Gy fraction) and altered regimens $(<2$ Gy and $>2 \mathrm{~Gy}$, for hyperfractionated and hypofractionated radiotherapy schedules, respectively) (Marcu 2010, Deloch et al. 2016).

Ex vivo analyses did not evidence any significant alteration of active caspase- 3 levels by irradiation and so does not permit any inference about radiation-induced apoptosis on G0lymphocytes. Changes on expression levels of active caspase- 3 were only observed in lymphocytes incubated for 24 hours minimum. This evidence is in accordance with other works, which assert that the apoptotic event occurs between 24 hours and 1 week after irradiation in gamma-irradiated human G0-lymphocytes exposed to the same dose levels here employed (Torudd et al. 2005, Belyaev 2010). Although most of the works investigate apoptosis by other biological endpoints, such as surface exposure of phosphatidylserine and cytoplasmic membrane permeability, they also did not recommend ex vivo or short-time analysis (e.g. 6 hours) for such purpose (Vokurková et al. 2006, Tavakoli et al. 2015). On our case, ex vivo analyses were employed as a control for in vitro conditions. 
For in vitro conditions, active caspase-3 expression allowed differentiation between nonirradiated and irradiated groups, for all doses (1, 2 and 4 Gy), indicating a close relation between active caspase- 3 and radiation-induced response of lymphocytes. Incubation during 24 hours was considered the better condition to visualize this relation, since just at this time point was possible to distinguish each dose within the dose range, evidencing the influence of IR exposure (Figure 2), with a positive trend (Figure 3). For $48 \mathrm{~h}$-incubation samples, it was not possible to distinguish between doses closer within the range (1 Gy from 2 Gy; 2 Gy from 4 Gy). For 72 h-incubated cells, no statically significant difference of active caspase-3 expression levels was found comparing any irradiated samples.

Similar researches indicate that human G0lymphocytes present a general trend to saturation of apoptosis-related dose response following gamma-ray irradiation and incubation at 48 and 72 hours. Belyaev 2010 emphasized that this behavior seems to be a trend of this kind of cell rather than a peculiarity of a specific time point or specific end-point. After 24 hours, the plateau has been observed from 5 up 10 Gy (Vral et al. 1998, Torudd et al. 2005). Data of the present work confirm this evidence and reinforces incubation during $24 \mathrm{~h}$ as the better condition to evaluate radiation-induced apoptosis on gamma-irradiated G0 lymphocytes for dose range up to $4 \mathrm{~Gy}$, based on the expression of active caspase- 3 .

Concerning the dose-dependent kinetic, apoptosis in peripheral blood lymphocytes has been suggested as a potential biological dosimeter. Most of these studies are based on the morphological appearance of the lethal process, like fragmentation and condensation of DNA or superficial phosphatidylserine exposure/ cytoplasmic membrane permeability (Boreham et al. 1996, Menz et al. 1997, Vokurková et al. 2006, Faraj et al. 2010). Unlike them, the present study extends apoptosis evaluation to an enzymological criterion, employing the same analytical tool, namely flow cytometry. The flow cytometry has emerged as a powerful analytical tool due to its rapidity and high sensitivity during analysis of a large number of cells (Adan et al. 2016). On the measurement of active caspase- 3 expression realized on the present work, we confirm the high efficacy of this technology on the determination of protein expression levels at few minutes after sample acquisition.

Focusing on one day-time post-irradiation analyses, it was identified that, despite all individuals had evidenced the influence of IR on active caspase-3 expression, individual results presented a high dispersion around mean values, more evident at higher doses (Figure 2). Analyzing separately each subject, differences on the magnitude of protein expression in response to the same dose levels are clearly significant (Figure 3), suggesting that the response (active caspase- 3 expression) to radiation-induced damage is dose-dependent, but varies significantly from person to person and so is determined by individual characteristics. This inter-individual variance has been related by several researches (Erasmus et al. 2005, Schnarr et al. 2007, Pinar et al. 2010).

The research line that defends the use of apoptosis assay as a rapid screening test for clinical prediction of late normal tissue toxicity following radiotherapy is still stronger than those indicating its employment for biodosimetric evaluations (Tavakoli et al. 2015). Effects on normal tissue often limiting clinical use of radiation involves delayed cycles of inflammation, tissue dysfunction, atrophy, and/or fibrotic remodeling (Panganiban et al. 2013). Studies point out that low apoptotic response is associated with risk for development of late side effects, which occur around 6 months to many years after exposure and, thus, demanding follow-up relatively long. Besides this, this kind of effect can be irreversible (Erasmus et al. 2005, 
Ozsahin et al. 2005, Bordón et al. 2009, Schnarr et al. 2009, Pinar et al. 2010).

The identification of radiation-sensitive group may orientate alterations on a therapeutic protocol that would involve reduction of radiotherapy dose or adoption of alternative therapy (Barnett et al. 2009, Marcu 2010, Deloch et al. 2016). Applying these evidence to normal subjects group analyzed in this work, individuals 2 and 3 may require a differentiate care during situations involving radiation exposure. Both exhibited low levels of radiation-induced expression of active caspase-3 that may indicate a higher risk for late side effects after a radiotherapy session, for example.

Concerning radiation protection management, works of Schnarr et al. 2007 and Cavalcanti et al. 2015 have pointed out the individual radiosensitivity as an important parameter to professionals and public at large. Today, dose limits are set to ensure exposure at safe levels, assuming that people have similar responses to IR. However, accepting that higher individual sensitivity increases the probability of development of long-term side effects of radiation exposure, maybe radiation protection regulations would consider dose limits tailored for such people.

On the other hand, there are some evidence of the unsuitability of such analysis to predict individual clinical radiosensitivity (Barber et al. 2000, Greve et al. 2009), indicating the need for further studies, particularly clinical trials, to wellestablish the aspects here observed. Validation of tests for early detection of exposure and prediction of individual radiosensitivity may be hereafter implemented in fields benefited by radiobiological advances, like medical and occupational practices and accidental exposures.

\section{CONCLUSIONS}

Our work contributes with a methodology for measuring active caspase-3 expression levels in human lymphocytes, stressing that apoptosis- related events require a minimal time to be triggered after gamma-radiation exposure of normal resting (G0) human peripheral blood lymphocytes. Shortterm incubation of $24 \mathrm{~h}$ appeared as the more suitable condition to investigate apoptosis induced by high-dose IR exposure based on active caspase-3 analyses, providing insights into general behavior and individual response. Thus, the proposed assay could be used as a tool for detecting differences in radiation sensitivity of patients before they undergo radiotherapy, in order to adjust the dose regimen to the patient response or even to prescribe an alternative therapy. Naturally, further studies are needed with a larger number of individuals to define the interval limits representative of a population for the same set of doses employed in this work.

\section{ACKNOWLEDGMENTS}

The authors would like to thank the Laboratory of Ionizing Radiation Metrology - Federal University of Pernambuco (LMRI/DEN-UFPE Brazil) for the use of their irradiation facilities; the Conselho Nacional de Desenvolvimento Científico e Tecnológico (CNPq - Brazil) and Fundação de Amparo à Ciência e Tecnologia de Pernambuco (FACEPE), for financial support.

\section{REFERENCES}

ADAN A, ALIZADA G, KIRAZ Y, BARAN Y AND NALBANT A. 2016. Flow cytometry: basic principles and applications. Crit Rev Biotechnol 14: 1-14.

AGARWAL P AND MILLER KM. 2016. The nucleosome: orchestrating DNA damage signaling and repair within chromatin. Biochem Cell Biol 94: 381-395.

BARBER JB, WEST CM, KILTIE AE, ROBERTS SA AND SCOTT D. 2000. Detection of individual differences in radiation-induced apoptosis of peripheral blood lymphocytes in normal individuals, ataxia telangiectasia homozygotes and heterozygotes, and breast cancer patients after radiotherapy, Radiat Res 153(5 Pt 1): 570-578.

BARNETT GC, WEST CM, DUNNING AM, ELLIOTT RM, COLES CE, PHAROAH PD AND BURNET NG. 2009. Normal tissue reactions to radiotherapy: towards tailoring treatment dose by genotype. Nat Rev Cancer 9: 134-142. 
BELYAEV IY. 2010. Radiation-induced DNA repair foci: spatio-temporal aspects of formation, application for assessment of radiosensitivity and biological dosimetry. Mutat Res 704: 132-141.

BENNETT DA AND WATERS WD. 2000. Applying biomarker research. Environ Health Perspect 108: 907910.

BOLKENT S, OZTAY F, GEZGINGI OKTAYOGLU S, SANCAR BAS S AND KARATUG A. 2016. A matter of regeneration and repair: caspases as the key molecules. Turk J Biol 40: 333-352.

BORDÓN E, HENRÍQUEZ HERNÁNDEZ LA, LARA PC, PINAR B, FONTES B, RODRÍGUEZ GALLEGO C AND LLORET M. 2009. Prediction of clinical toxicity in localized cervical carcinoma by radio-induced apoptosis study in peripheral blood lymphocytes (PBLs). Radiat Oncol 4: 58 .

BOREHAM DR, GALE KL, MAVES SR, WALKER JA AND MORRISON DP. 1996. Radiation-induced apoptosis in human lymphocytes: potential as a biological dosimeter. Health Phys 71: 685-691.

CAVALCANTI MB, FERNANDES TS, SILVA EB AND AMARAL A. 2015. Correlation between radiation dose and p53 protein expression levels in human lymphocytes. An Acad Bras Cienc 87: 1783-1790.

CHOI WH AND CHO J. 2016. Evolving clinical cancer radiotherapy: concerns regarding normal tissue protection and quality assurance. J Korean Med Sci 31(Suppl 1): S75-S87.

COELHO D, HOLL V, WELTIN D, LACORNERIE T, MAGNENET P, DUFOUR P AND BISCHOFF P. 2000. Caspase-3-like activity determines the type of cell death following ionizing radiation in MOLT-4 human leukaemia cells. Br J Cancer 83: 642-649.

COZZARINI C. 2015. Radiation induced lymphocyte apoptosis: an effective way of "tailoring" radiotherapy to the right patients only? EBioMedicine 2: 1852-1853.

DAUB H. 2012. DNA damage response: multilevel proteomics gains momentum. Mol Cell 46: 113-114.

DELOCH L, DERER A, HARTMANN J, FREY B, FIETKAU R AND GAIPL US. 2016. Modern radiotherapy concepts and the impact of radiation on immune activation. Front Oncol 6: 141.

ELMORE S. 2007. Apoptosis: a review of programmed cell death. Toxicol Pathol 35: 495-516.

ERASMUS WL, SLABBERT JP, CROMPTON N AND MEEHAN KA. 2005. The leukocyte apoptosis assay: a clinical predictor of radiosensitivity. Medical Technology 19: 9-14.

ERIKSSON D AND STIGBRAND T. 2010. Radiationinduced cell death mechanisms. Tumour Biol 31: 363-372.

FARAJ KA, ELIAS MM AND BAATOUT S. 2010. Effects of $\mathrm{X}$ and gamma rays on human lymphocytes. Romanian $\mathrm{J}$ Biophys 20: 355-367.
GALLUZZI L, JOZA N, TASDEMIR E, MAIURI MC, HENGARTNER M, ABRAMS JM, TAVERNARAKIS N, PENNINGER J, MADEO F AND KROEMER G. 2008. No death without life: vital functions of apoptotic effectors. Cell Death Differ 15: 1113-1123.

GARCIA-BELINCHÓN M, SÁNCHEZ-OSUNA M, MARTÍNEZ-ESCARDÓ L, GRANADOS-COLOMINA C, PASCUAL-GUIRAL S, IGLESIAS-GUIMARAIS V, CASANELLES E, RIBAS J AND YUSTE VJ. 2015. An early and robust activation of caspases heads cells for a regulated form of necrotic-like cell death. J Biol Chem 290: 20841-20855.

GREVE B ET AL. 2009. Multicentric investigation of ionising radiation-induced cell death as a predictive parameter of individual radiosensitivity. Apoptosis 14: 226-235.

HALLIWELL B. 2003. Oxidative stress in cell culture: an under-appreciated problem? FEBS Lett 540: 3-6.

HALLIWELL B. 2014. Cell culture, oxidative stress, and antioxidants: avoiding pitfalls. Biomed J 37: 99-105.

JELLA KK, GARCIA A, MCCLEAN B, BYRNE HJ AND LYNG FM. 2013. Cell death pathways in directly irradiated cells and cells exposed to medium from irradiated cells. Int J Radiat Biol 89: 182-190.

JOUBERT A, VOGIN G, DEVIC C, GRANZOTTO A, VIAU M, MAALOUF M, THOMAS C, COLIN C AND FORAY N. 2011. Radiation biology: major advances and perspectives for radiotherapy. Cancer Radiother 15: 348354.

KHALIL H ET AL. 2012. Caspase-3 protects stressed organs against cell death. Mol Cell Biol 32: 4523-4533.

KIM D ET AL. 2013. Nanosensor dosimetry of mouse blood proteins after exposure to ionizing radiation. Sci Rep 3: 2234.

KORNACKER M, VERNERIS MR, KORNACKER B, SCHEFFOLD C AND NEGRIN RS. 2001. Survivin expression correlates with apoptosis resistance after lymphocyte activation and is found preferentially in memory T cells. Immunol Lett 76: 169-173.

KURANAGA E. 2010. Beyond apoptosis: caspase regulatory mechanisms and functions in vivo. Genes Cells 17: 83-97.

LAUNAY S, HERMINE O, FONTENAY M, KROEMER G, SOLARY E AND GARRIDO C. 2005. Vital functions for lethal caspases. Oncogene 24: 5137-5148.

LAVIN MF, KOZLOV S, GATEI M AND KIJAS AW. 2015. ATM-dependent phosphorylation of all three members of the MRN complex: from sensor to adaptor. Biomolecules 5: 2877-2902.

MAIER P, HARTMANN L, WENZ F AND HERSKIND C. 2016. Cellular pathways in response to ionizing radiation and their targetability for tumor radiosensitization. Int $\mathrm{J}$ Mol Sci 17: E102.

MARCU LG. 2010. Altered fractionation in radiotherapy: from radiobiological rationale to therapeutic gain. Cancer Treat Rev 36: 606-614. 
MATT S AND HOFMANN TG. 2016. The DNA damageinduced cell death response: a roadmap to kill cancer cells. Cell Mol Life Sci 73: 2829-2850.

MCILWAIN DR, BERGER T AND MAK TW. 2013. Caspase functions in cell death and disease. Cold Spring Harb Perspect Biol 5: a008656.

MENZ R, ANDRES R, LARSSON B, OZSAHIN M, TROTT K AND CROMPTON NE. 1997. Biological dosimetry: the potential use of radiation-induced apoptosis in human T-lymphocytes. Radiat Environ Biophys 36: 175-181.

OGAWA Y. 2016. Paradigm shift in radiation biology/ radiation oncology - exploitation of the " $\mathrm{H}_{2} \mathrm{O}_{2}$ effect" for radiotherapy using low-LET (Linear Energy Transfer) radiation such as $\mathrm{X}$-rays and high-energy electrons. Cancer (Basel) 8: 28.

OZSAHIN M, CROMPTON NE, GOURGOU S, KRAMAR A, LI L, SHI Y, SOZZI WJ, ZOUHAIR A, MIRIMANOFF RO AND AZRIA D. 2005. CD4 and CD8 T-lymphocyte apoptosis can predict radiation-induced late toxicity: a prospective study in 399 patients. Clin Cancer Res 11: 7426-7433.

PALAI TP AND MISHRA SR. 2015. Caspases: an apoptosis mediator. J Adv Vet Anim Res 2: 18-22.

PANGANIBAN R-AM, SNOW AL AND DAY RM. 2013. Mechanisms of radiation toxicity in transformed and nontransformed cells. Int J Mol Sci 14: 15931-15958.

PINAR B, HENRÍQUEZ-HERNÁNDEZ LA, LARA PC, BORDON E, RODRIGUEZ-GALLEGO C, LLORET M, NUÑEZ MI AND ALMODOVAR MR. 2010. Radiation induced apoptosis and initial DNA damage are inversely related in locally advanced breast cancer patients. Radiat Oncol 5: 85.

PINTO MM, SANTOS NF AND AMARAL A. 2010. Current status of biodosimetry based on standard cytogenetic methods. Radiat Environ Biophys 49: 567-581.

RODEMANN HP AND WOUTERS BG. 2011. Frontiers in molecular radiation biology/oncology. Radiother Oncol 101: 1-6.

ROSS WP AND KAINA B. 2013. DNA damage-induced apoptosis: from specific DNA lesions to the DNA damage response and apoptosis. Cancer Lett 332: 237-248.

SANTOS NFG, FREITAS-SILVA R, PEREIRA VRA, TASAT DR AND AMARAL A. 2013. Análise por citometria de fluxo da expressão da proteína p21 em linfócitos humanos irradiados. Scientia Plena 9: 081001-1.

SAVISTSKAYA MA AND ONISHCHENKO GE. 2015. Mechanisms of apoptosis. Biochemistry (Mosc) 80: 13931405.

SCHNARR K, BOREHAM D, SATHYA J, JULIAN J AND DAYES IS. 2009. Radiation-induced lymphocyte apoptosis to predict radiation therapy late toxicity in prostate cancer patients. Int J Radiat Oncol Biol Phys 74: 1424-1430.
SCHNARR K, DAYES I, SATHYA J AND BOREHAM D. 2007. Individual radiosensitivity and its relevance to health physics. Dose Response 5: 333-348.

SELZER E AND HEBAR A. 2012. Basic principles of molecular effects of irradiation. Wien Med Wochenschr 162: 47-54.

SHALINI S, DORSTYN L, DAWAR S AND KUMAR S. 2015. Old, new and emerging functions of caspases. Cell Death Differ 22: 526-539.

SLEE EA, ADRAIN C AND MARTIN SJ. 2001. Executioner caspase-3, -6, and -7 perform distinct, non-redundant roles during the demolition phase of apoptosis. J Biol Chem 276: 7320-7326.

SRIDHARAN DM ET AL. 2016. Evaluating biomarkers to model cancer risk post cosmic ray exposure. Life Sci Space Res (Amst) 9: 19-47.

TAVAKOLI MB, KHEIROLLAHI M, KIANI A, KAZEMI M, JAVANMARD SH AND MOHEBAT L. 2015. Annexin $\mathrm{V}$ FITC conjugated as a radiation toxicity indicator in lymphocytes following radiation overexposure in radiotherapy programs. Adv Biomed Res 4: 119.

TEWARI S, KHAN K, HUSAIN N, RASTOGI M, MISHRA SP AND SRIVASTAV AK. 2016. Peripheral blood lymphocytes as in vitro model to evaluate genomic instability caused by low dose radiation. Asian Pac J Cancer Prev 17: 1773-1777.

TORUDD J, PROTOPOPOVA M, SARIMOV R, NYGREN J, ERIKSSON S, MARKOVA E, CHOVANEC M, SELIVANOVA G AND BELYAEV IY. 2005. Doseresponse for radiation-induced apoptosis, residual 53BP1 foci and DNA-loop relaxation in human lymphocytes. Int J Radiat Biol 81: 125-138.

TRISCIUOGLIO J AND BIANCHI ME. 2009. Several nuclear events during apoptosis depend on caspase-3 activation but do not constitute a common pathway. PLoS One 4: e6234.

ULSH BA. 2010. Checking the foundation: recent radiobiology and the linear no-threshold theory. Health Phys 99: 747758.

VOKURKOVÁ D, ŠINKORA J, VÁVROVÁ J, ŘEZÁČOVA M, KNIŽEK J AND ÖSTEREICHER J. 2006. CD8+ natural killer cells have a potential of a sensitive and reliable biodosimetric marker in vitro. Physiol Res 55: 689-698.

VRAL A, CORNELISSEN M, THIERENS H, LOUAGIE H, PHILIPPÉ J, STRIJCKMANS K AND DE RIDDER L. 1998. Apoptosis induced by fast neutrons versus $60 \mathrm{Co}$ gamma-rays in human peripheral blood lymphocytes. Int J Radiat Biol 73: 289-295.

YANG J-Y, MICHOD D, WALICKI J, MURPHY BM, KASIBHATLA S, MARTIN SJ AND WIDMANN C. 2004. Partial cleavage of RasGAP by caspases is required for cell survival in mild stress conditions. Mol Cell Biol 24: $10425-10436$. 